\title{
Cadmium and lead occurrence in soil and grape from Murfatlar Vineyard
}

\author{
Nicoleta MATEI, ${ }^{\mathrm{a}}$ Antoanela POPESCU*, ${ }^{*}$ Gabriel-Lucian RADU, ${ }^{\mathrm{c}}$ Victoria ARTEM $^{\mathrm{d}}$ and Georgeta \\ PAVALACHE ${ }^{\mathrm{b}}$ \\ ${ }^{a}$ Faculty of Applied Sciences and Engineering, Ovidius University, Constanţa, 900527, Romania \\ ${ }^{b}$ Faculty of Pharmacy, Ovidius University Constanța, Constanţa, 900527, Romania \\ ${ }^{c}$ National Institute for Biological Science, Centre of Bioanalysis, 296, Splaiul Independentei, Bucharest, 060031, \\ Romania \\ ${ }^{d}$ Research Centre for Viticulture and Enology Murfatlar, Constanţa, Romania
}

\begin{abstract}
The study investigates the pollution with heavy metals of grapes and soil. The grapes nourish from the respective soil, with all existing substances: either nutrients or toxic materials. This link, between grapes and soil, made mandatory to focus on observing the level of toxic materials in both samples grapes and land. The aim of this research is to analyze the level of $\mathrm{Cd}$ and $\mathrm{Pb}$ in Vitis vinifera $\mathrm{L}$. grape fruits and soil, by flame atomic absorption spectrometry (FAAS) method. The grapes and the soil used in this work were sampled from the Murfatlar City, a nonindustrial area, placed far from the car traffic pollution. $\mathrm{Cd}$ and $\mathrm{Pb}$ were quantified, after the chemical mineralization of the samples using nitric acid. It can be noticed that the values of cadmium and lead concentrations in grapes were lower than the recommendable maximum limit.
\end{abstract}

Keywords: cadmium, lead, grape, soil, FAAS.

\section{Introduction}

Heavy metals are serious pollutants due to their toxicity, persistence in natural conditions and ability to be incorporated into food chains [1].

Human health is very important to our survival [2]. Plants can contain metallic species taken from the soil, water or air. Dosage of various metals in samples of grapes is important from toxicology point of view, because grapes contain several elements that, in high concentrations, are harmful to the human body ( $\mathrm{Pb}, \mathrm{As}$ or $\mathrm{Cd})$ [3].

The plants usually translocate larger quantities of metals to their leaves, rather than to their fruits or seeds. Some of them do not tolerate higher levels of metals, but they hyper-accumulate $\mathrm{Cd}$ [4].

Lead is a naturally occurring element, but at levels higher than $0.5-0.8 \mathrm{mg} / \mathrm{mL}$ in the blood it causes different faults. Cadmium is a heavy metal, carcinogen to humans and toxic to plants $[5,6]$.

Lead occurs naturally in the soil. Most of lead concentrations that are found in the environment are due to the human activities. Due to the use of lead in gasoline an unnatural lead-cycle has generated. Lead is burned in car engines and lead salts (chlorines, bromines, oxides) will originate. Lead toxicity results in several ill effects, such as disruption of the biosynthesis of haemoglobin and anaemia, a rise in blood pressure, kidney damage, miscarriages and subtle abortions, disruption of nervous systems and brain damage, etc. [7].

Cadmium has no vital biological function but it is highly toxic to plants and animals. The soil standard levels of $0.06-1.1 \mathrm{mg} / \mathrm{kg}$ can be considerably increased by deposition from the industrial waste, sludge application and impurities from phosphatic fertilizers [8]. It has high concentration at surface soils where it is retained by the organic matter. It can also move down the soil profile depending on soil and site factors. In the soil solution, the $\mathrm{Cd}^{2+}$ free ion is the principal and most toxic species, but its organic and inorganic complexes also exist [9].

According to the Romanian Ministry of Water, Forestry and Environmental Protection, the critical areas, as far as the soil pollution is concerned, are: Ramnicu Valcea, Bacau, Dolj and Constanta - due to the deposits of hazardous industrial wastes [10]. 
Murfatlar Vineyard, placed in Constanta County, was chosen to be the experimental environment for this research, in order to check cadmium and lead occurrence in soil (at different depths: surface, 20 $\mathrm{cm}$ and $40 \mathrm{~cm}$ ) and grape (peel, seed and pulp).

\section{Experimental}

\subsection{Reagents and solutions}

Analytical grade chemicals $\left(\mathrm{HNO}_{3} \quad 65 \%\right.$, hydrogen peroxide $30 \%, \mathrm{Cd}^{2+}$ and $\mathrm{Pb}^{2+}$ certified analytical standard solutions of $1000 \mathrm{mg} / \mathrm{L}$ Merck and Fluka) were used. All chemicals were of analytical reagent grade (purity $>98 \%$ ) and used without further purification. All the solutions were prepared using ultrapure water from a Milli-Q Elix3 system.

\subsection{Sampling and sample preparation}

Five varieties of Murfatlar grapes were studied: Cabernet Sauvignon, Riesling Italian, Pinot Noir, Columna and Mamaia. Samples were taken during ripening grapes in the vineyard Murfatlar, in three different times during 17 August - 9 September 2013.

A homogeneous sample of each varieties fresh grape from the Murfatlar Vineyard was collected. In order to determine metal concentrations, the samples were washed with deionized water, carefully separated into peel, pulp and seeds, dried and homogenized. $0.5-0.9 \mathrm{~g}$ of each dry sample were subjected to digestion with $8 \mathrm{~mL} \mathrm{HNO}_{3} 65 \%$ and 10 $\mathrm{mL} \mathrm{H}_{2} \mathrm{O}_{2} 25 \%$ at $150^{\circ} \mathrm{C}$ in a Digesdhal device provided by Hach Company. After the complete digestion, the samples solution was filtered and transferred to a $50 \mathrm{~mL}$ volumetric flask with deionized water.

Soil samples were collected from each of five varieties of selected plant samples origin in at three depths: surface, $20 \mathrm{~cm}$ and $40 \mathrm{~cm}$ simultaneously. 5 $\mathrm{g}$ of soil samples from the selected sites were dried at $105{ }^{\circ} \mathrm{C}$ to constant weight in a drying chamber. Then, after $10 \mathrm{~mL}$ of distillated water were added, the samples homogenized and dried for one hour at sand bath. The samples were digested with $10 \mathrm{~mL}$ $\mathrm{HNO}_{3} 2 \%$ for two hours. The mixtures were filtered and diluted to $50 \mathrm{~mL}$ deionized water [4].

Analysis of the filtered mixture was conducted by atomic absorption method [11].

\subsection{Sample analysis and instruments}

$\mathrm{Cd}$ and $\mathrm{Pb}$ were determined by flame atomic absorption spectrometry (FAAS) in air/acetylene flame using an aqueous standard calibration curve. Analyses were made in triplicate and the mean values are reported. The FAAS instrument used was a GBC Avanta Flame Atomic Absorption Spectrometer. Concentrations of metals were measured using monoelement hollow cathode lamp.

The main characteristics of the equipment for metals determination are presented in Table 1. The method has been described and standardized in the literature [11].

Table 1. Technical characteristics of metal determination using FAAS.

\begin{tabular}{|c|c|c|c|c|}
\hline & \multirow{2}{*}{$\begin{array}{c}\lambda \\
(\mathrm{nm})\end{array}$} & $\begin{array}{c}\text { Optimal } \\
\text { concentration } \\
\text { range } \\
\end{array}$ & & \multicolumn{2}{|c|}{$\begin{array}{c}\text { Gases flow } \\
(\mathrm{m} / \mathrm{min})\end{array}$} \\
\cline { 4 - 5 } & & & Air & Acetylene \\
\hline $\mathrm{Cd}$ & 228.8 & $0.01-0.5$ & 10.0 & 1.1 \\
\hline $\mathrm{Pb}$ & 217.0 & $0.2-2.0$ & 10.0 & 1.2 \\
\hline
\end{tabular}

\section{Results and Discussions}

The assessment of metals contents in grapes represents one of the factors in the evaluation of their quality taking into consideration that some plants may accumulate particular metals, especially cadmium.

Cadmium and lead are the heavy metals of most concern because they may affect human health.

Figure 1 presents the average values of $\mathrm{Cd}$ and $\mathrm{Pb}$ concentrations in peel, pulp and seed of different varieties of grapes. The highest metal concentration found is lead $(0.105 \mathrm{mg} / \mathrm{Kg})$, while cadmium was $0.078 \mathrm{mg} / \mathrm{kg}$ in fruits assessed. The recommendable maximum limits for metals in fruits are $0.05 \mathrm{mg} / \mathrm{Kg}$ for $\mathrm{Cd}$ and $0.1 \mathrm{mg} / \mathrm{Kg}$ for $\mathrm{Pb}[12,13]$. It can be noticed that the values of cadmium and lead concentrations in grapes are lower than the recommendable maximum limit of these metals in fruits.

The precision of the method was evaluated by intra-day assays using standard solutions, grapes and soil samples. Every sample solution of the same concentration was analyzed at least six times to determine the relative standard deviation (RSD) values. The RSD values obtained ranged from 
$0.46 \%$ to $1.76 \%$. The obtained RSD values (below $2 \%$ ) indicated an excellent precision (repeatability) of the proposed method.

Angelova et al. found $0.4 \mathrm{mg} / \mathrm{kg} \mathrm{Pb}$ in skins of grapes, $0 \mathrm{mg} / \mathrm{kg} \mathrm{Pb}$ in pulp and $2.0 \mathrm{mg} / \mathrm{kg} \mathrm{Pb}$ in seeds of grapes of Pleven Region, Bulgaria [14]. Also, they not found cadmium in studied grapes samples. The results for lead concentrations in grapes are higher than our results from the Murfatlar Region.

Alshammary et al. found $0.074 \mathrm{mg} / \mathrm{kg}$ cadmium in grape samples (the entire fruit) of different agricultural companies in Saudi Arabia [15]. Also, the entire fruit were studied by Sobukola et al. [16]. They found a mean of cadmium concentration by $0.003 \mathrm{mg} / \mathrm{kg}$. in grape samples of Lagos, Nigeria. In Misurata area, Libya the mean of cadmium concentration is $0.05 \mathrm{mg} / \mathrm{kg}$ [17]. Those values are comparable with our results.

In India, Mahdavian et al. found $7.05 \mathrm{mg} / \mathrm{kg}$ cadmium concentration in Bangalore City Markets grapes [18]. This value is higher than the present study results (Figure 1).

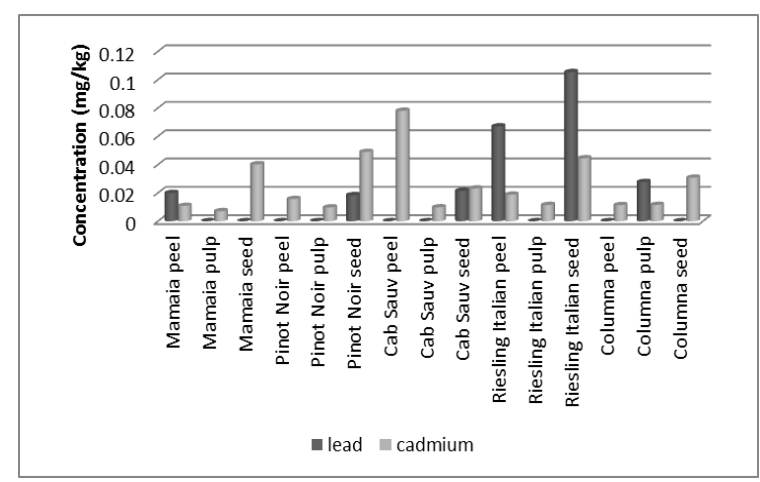

Fig. 1. Heavy metals occurrence in peel, pulp and seed of five varieties of grapes $(\mathrm{Cab}$ Sauv $=$ Cabernet Sauvignon).

Evaluation of heavy metals in soils of Murfatlar vineyard showed that amounts of some heavy metals in the soils samples were lower than the recommendable maximum limit of these metals in vineyard soils (Figures $\mathbf{2}$ and 3). The regular limit of these metals in vineyard soils was $1 \mathrm{mg} / \mathrm{kg}$ for cadmium and $20 \mathrm{mg} / \mathrm{kg}$ for lead [19].

After analyzing the evidence, it was found that on average lead concentration in soil is higher than that of cadmium. The highest lead concentration values were recorded on the ground surface which is cultivated variety Mamaia and at a depth of $40 \mathrm{~cm}$ soil where it is grown variety Columna.

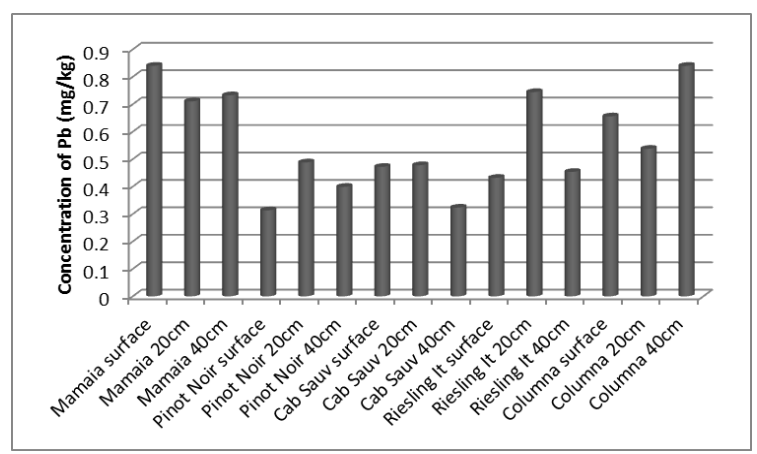

Fig. 2. Lead concentration in soil at three depths.

The highest concentration of cadmium was recorded at a depth of $20 \mathrm{~cm}$ soil where it is grown Cabernet Sauvignon. Also, grape peel of this variety has a higher concentration of cadmium than other grape samples analyzed.

Concentration levels of determined heavy metals present an insignificant variation during the ripening of the grapes.

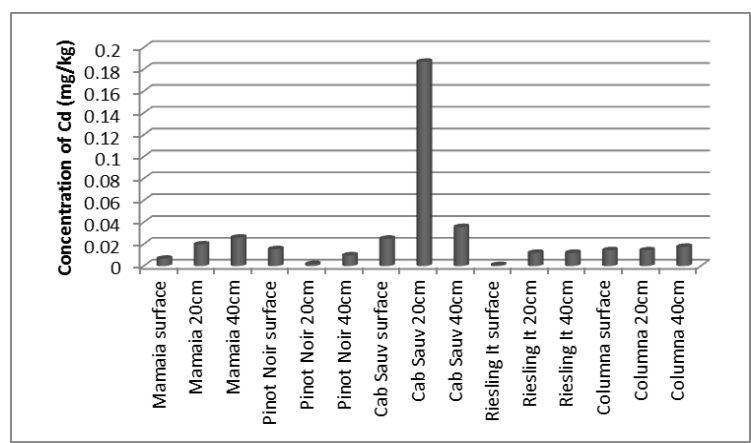

Fig. 3. Cadmium soil levels for five varieties of grapes at three depths.

Halili et al. have determined the concentration of $\mathrm{Pb}$ and $\mathrm{Cd}$ in soil samples of vineyards in Rahovec, Kosovo and they found $1.043 \mathrm{mg} / \mathrm{kg} \mathrm{Cd}$ at $50 \mathrm{~m}$ away from roadway while the highest concentration of $\mathrm{Pb}(24.32 \mathrm{mg} / \mathrm{kg})$ were found near the roadway [20]. Those values are highest than the results of our study.

Plants can contain the metals from soil, water and air. High heavy metals uptake can also be found in some regions due to certain properties of soil $(\mathrm{pH}$, 
organic matter) which favor the mobility of metals in soil and their availability of metals in soil and their availability to plants [21]. Usually, the vineyards have reticular system under $40 \mathrm{~cm}$ [19].

\section{Conclusions}

This paper presents original data concerning the $\mathrm{Cd}$ and $\mathrm{Pb}$ content in grapes fruits and in soils. Cadmium and lead are the heavy metals of most concern because they may affect human health.

$\mathrm{Cd}$ and $\mathrm{Pb}$ metal concentrations in the soil fall into the normal range. They have not accumulated in alarming limits and not influenced grape quality. The geographic area studied is relatively insulated from potential pollutants factors, Murfatlar is renowned for the quality of the wines.

Environmental pollution is a global problem, reported in the literature, especially heavy metal pollution. Soil can accumulate these heavy metals over time, sometimes reaching above the permissible limits. But in this study it can be noticed that the values of cadmium and lead concentrations in grapes are lower than the recommendable maximum limit of these metals in fruits.

\section{References}

*E-mail address: antoniapopescu2002@yahoo.co.uk

[1]. H. Zang, B. Cui, R. Xiao and H. Zhao, Procedia Environmental Sciences 2, 1344, (2010).

[2]. S.C. Emine, A. Duygu, T. Ecehan, B. Nilgü and B. Göktürk, Industrial Crops and Products 34, 994 (2011).

[3]. I. Vinkovic Vrcek, M. Bojic, I. Zuntar, G. Mendaš and M. Medic-Šaric, Food Chemistry 124, 354 (2011).

[4]. D. Diaconu, V. Nastase, M.M. Nanau, O. Nechifor and E. Nechifor, Environmental Engineering and Management Journal 8, 569 (2009).

[5]. R.K. Sharma, M. Agrawal and F.M. Marshall, Environ. Poll. 154, 254 (2008).

[6]. T. Oymak., S. Tokalioglu, V. Yılmaz, S. Kartal and D. Aydin, Food Chemistry 113, 1314 (2009).
[7]. A.A. Waoo, S. Khare, S. Ganguli, Journal of Environment and Human 1, 2373 (2014).

[8]. B.J. Alloway and B. Alloway, Heavy metals in soils. Blackie, Glasgow, (1995).

[9]. B.S. Bada and K.A. Raji, African Journal of Environmental Science and Technology 4, 250 (2010).

[10]. L. Constantinescu, Bulletin UASVM, Agriculture 65, 50 (2008).

[11]. N. Lupascu, E. Chirila and M. Munteanu, Ovidius University Annals of Chemistry 20, 232 (2009).

[12]. *** Order no. $975 / 1998$ of the Romanian Ministry of Public Health. Maximum permissible limits of metals in food, (1998).

[13]. *** COMMISSION REGULATION (EC) No $1881 / 2006$, Official Journal of the European Union, L 364/5, (2006).

[14]. V.R. Angelova, A.S. Ivanov and D.M. Braikov, Journal of the Science of Food and Agriculture 79, 713 (1999).

[15]. S.F. Alshammary and O.S. Al-Horayess, Oriental Journal of Chemistry 29, 1515 (2013).

[16]. O.P. Sabukola, O.M. Adeniran, A.A. Aderairo and O.E. Kajihaisa, African Journal of Food Science 4, 389 (2010).

[17]. M.A. Elbagermi, H.G.M. Edwards and A.I. Alajtal, ISRN Analytical Chemistry, 2012, (2012).

[18]. S.E. Mahdavian, R.K. Somashekar and K. R. Kathmandu, University Journal of Science, Engineering and Tehnology 1, 17 (2008).

[19]. E. Chirila and C. Draghici, Poluarea si analiza poluantilor din produse alimentare si din mediu (in Romanian, Pollution and analysis of pollutants in food and environment), Ovidius University Press, pp. 76 - 77 (2013).

[20]. J. Halili, K. Bislimi, I. Mazreku, F. Osmani, A. Maloku and F. Halili, $13^{\text {th }}$ SGEM GeoConference an Ecology, Economics, Education and Legislation, SGEM 13 Conference Procedeengs, ISBN 978-619-04-9/ ISSN 1314-2704, 1, 531 (2013).

[21]. I. Odriozola-Serrano, T. Hernandes_Jover, O. Martin-Belloso, Food Chmenistry 105, 1151 (2009)

Received: 19 April 2015 Received in revised form: 4 June 2015 Accepted: 5 June 2015 